\title{
ATTITUDES OF MANAGERS TOWARDS DISADVANTAGED GROUPS ON THE LABOUR MARKET IN THE SLOVAK REPUBLIC
}

\author{
René Pawera, Vladimíra Pazderová, Marian Šuplata
}

\section{Introduction}

The issue of equal opportunities in the labour market is a highly topical issue, requiring the public attention. Considering that the Slovak Republic is already more than ten years a member of the European Union, it is necessary to address the issue not only on the national but also on the supranational level. The institutions of the European Union, using various instruments and taking complementary actions are trying to ensure equal opportunities in the labour market of the EU. To help achieving this objective, it is, however, necessary to ensure enforcing equal opportunities, as well as efforts and actions taken by individual Member States. Despite some progress made in the area of equal opportunities in the EU labour market and gradually leads to elimination of discriminatory conduct based on common characteristics such as age, sex or disability, Slovak Republic significantly lags behind the EU average. Moreover, there are existing prejudges towards some groups in the Slovak labour market. The main reason for selecting this issue was their common interest was twofold. Firstly, to address the current situation of disadvantaged groups in the labour market of the Slovak Republic. Secondly, the authors wished to contribute to improving the current state of play that seems to remain to be an open-ended process.

The results of various studies clearly confirm that the phenomenon of discrimination on the labour market exists. This statement is justified not only by job-seekers, but also by employees as well as managers themselves. The reason for this discrimination can be various: health, racial or ethnic origin, sex, religious belief, age or others. It seems neither the society, nor the individual responsible authorities pay sufficient attention to deal with this problem in an efficient way.

So far it has been paid a very limited attention to complex and comprehensive surveys on disadvantaged groups on the Slovak labour market that would in particular take into account the perception of these groups by the managers as representatives of potential employer of job seekers from the disadvantaged groups. Institutions as well as individual authors mostly focus on individual and group characteristics; however a complex look at this area is still missing. This perhaps might also be one of the reasons of the fundamental problem of perception of disadvantaged groups among the public. This is naturally reflected in perception, acceptance and persistence of discrimination.

The main aim of this paper is to reveal the current situation of selected disadvantaged groups on the labour market in the Slovak Republic from the point of view of managers of selected organisations, using the method of questionnaire survey. In the context of developments in selected research periods $(2008,2014)$ we tried to examine the attitudes of managers of organisations in the Slovak Republic in relation to selected disadvantaged groups and to verify the existence of discriminatory behaviour of managers against these groups.

\section{Theoretical Aspects of the Topic}

The Slovak legislation in the Employment Services Act no. 5/2004 [22] defines disadvantaged jobseekers as citizens who in respect to their age, length of their registration for job, lack of experience, state of health, loss of ability to carry out their previous employments, family reasons or position in the society have difficulties to find an employment on the labour market and this group undoubtedly needs increased attention of the society. The Article 8 [22] specifies fifteen disadvantaged labour market participants groups. The classification into these groups is based on the following factors: the age, the impossibility 
of reconciling family and work life, longterm unemployment, disability, nationality, migration, education or imprisonment.

These factors negatively affect the chances of the disadvantaged people and undermine their position on the labour market in comparison to the majority population. These groups of disadvantaged people, with regard to their living and social situation, are less or completely unattractive to employers. [8]

Vagač [17] defines disadvantaged labour market participants as a group, facing major difficulties in finding a job, to remain in it, or, to achieve higher earnings, while being aboveaverage risk of discrimination. The authors also present the key issues of the current approach to disadvantaged groups, such as: low efficiency of labour market policies, the discouraging effects of social benefits, the weak response of the education system to the demands of the labour market, low elasticity of labour legislation, high levy burden low-income groups and gaps in the practical application of anti-discrimination legislation.

According to Vágnerová [18], the labour market disadvantage is defined by the sociodemographic characteristics - age, sex, social group, and education.

This paper perceives the disadvantaged position on the labour market as a result of selected factors and qualities that significantly contribute to reducing the value of "human capital" by employers. This often leads to greater endangering of the persons concerned on the labour market. "Disadvantage" might also be perceived as the result of differentiation of selected groups and labour market participants.

Paprčka [7] argues that disadvantaged groups are marginalized, pushed aside to the edge of a group of people, often being subject to social and cultural isolation and various forms of discrimination. Before proposing our analysis of the state of play of selected aspects of disadvantaged groups on the labour market we see appropriate to define the term "discrimination".

According to Arrow [2], discrimination in the labour market is defined as "the valuation in the market place of personal characteristics of the worker that are unrelated to worker productivity. These personal characteristics may be sex, race, height, appearance, age, national origin," or "indeed any other identifiable characteristic."
This definition is in principle shared by other authors. Baldwin [3] states that "the employer hiring uncertainty results from the lack of predictability of worker productivity." Yinger [19] defines discrimination as "the unfavourable treatment of a person based solely on the basis of that person's membership in a protected class." According to Altonji and Blank [1], the employment discrimination "is said to arise when two identically productive workers are treated differently on the grounds of the worker's race or gender, race or gender when do not in themselves have an effect on productivity."

These definitions basically correspond to the perception of discrimination on the labour market as defined by the World Bank [20]: "labour market discrimination is defined as the systematically different treatment reserved to members of a given group, just because they belong to that group".

Based on the definitions of discrimination and definitions of disadvantaged groups in the labour market of the Slovak Republic the most affected and at-risk people include people from groups based on the following characteristics: Sex; Ethnic / Racial origin; Age; Disability.

Following these characteristics we distinguish the following disadvantaged groups on the labour market: Women; Persons belonging to the Roma ethnic group; Persons younger than 26 years - graduates who have completed vocational training; Elderly (above 50 years); Disabled persons. The relation between the characteristics and the disadvantaged groups can be seen in Table 1.

The position of these groups on the labour market might be improved by ensuring equal opportunities on the labour market and by promoting non-discrimination principles. By equal opportunities the European Union [6] understands an equitable distribution of the possibilities of education, training, employment, career development among individuals without prejudice to discrimination because of sex, race, language, religion, economic or family situation, and so on.

According to Eger and Indruchová, diversity management has gradually become a topical and important issue in the field of the development and use of human resources, namely after the Czech Republic joined the European Union [5].

In terms of the Slovak Republic, the equal opportunity principle is enshrined in the 
Tab. 1: Most disadvantaged groups in the labour market according selected characteristics

\begin{tabular}{l|l}
\multicolumn{1}{c|}{ General characteristics } & \multicolumn{1}{c}{ Disadvantaged groups } \\
\hline Sex & Women \\
\hline Ethnic/racial origin & Persons belonging to the Roma ethnic group \\
\hline \multirow{2}{*}{ Age } & $\begin{array}{l}\text { Persons younger than 26 years - graduates who have } \\
\text { completed vocational training }\end{array}$ \\
\cline { 2 - 2 } & Elderly (above 50 years) \\
\hline Disability & Disabled \\
\hline
\end{tabular}

Constitution, which in the Article 12 states that: people are "free and equal in dignity and rights". The fundamental rights and freedoms are guaranteed in the Slovak Republic to "everyone regardless of sex, race, colour of skin, language, faith and religion, political, or other thoughts, national or social origin, affiliation to a nation, or ethnic group, property, descent, or any other status". As stated in the article 12, these rights are "inviolable, inalienable, imprescriptible, and indefeasible" [21].

Equal opportunities on the labour market stems from the equal rights of individuals, taking into account the prohibition of discrimination on the basis of the characteristics defined by the Law (age, sex, race, etc.). Equal opportunities, however, do not automatically constitute equal conditions on the labour market, because in relation to age, disability, or sex of the entrants to the labour market. Unemployment and social exclusion is a very strong negative externality [9]. It is necessary to provide a variety of factors aimed at the creation of equal opportunities on the labour market. Groups and individuals on the labour market are always unique and original. Therefore this concept of equal opportunities in the Slovak Republic does not haveanaspiration of "the sameness".

\section{Objective and Methodology}

This paper focuses on the current situation of the position of disadvantaged groups on the labour market of the Slovak Republic. By the method of questionnaire survey of selected employers, represented by their managers we were examining their attitudes towards selected groups on the labour market. Furthermore we examined their motives in relation to the employment of selected candidates pointing to the discriminatory or non-discriminatory behaviour of managers on the Slovak labour market. The main aim of the research is to show the evolution of the labour market in terms of disadvantaged groups in order to identify whether any change of the situation of selected groups of participants on the labour market occurred. The purpose of our analysis is also to verify whether managers discriminate selected groups of participants on the labour market intentionally and whether there exists any shift in the perception of these groups by the managers.

In order to fulfil this objective we conducted a questionnaire survey focused on selected managers of organisations, in two reference periods: 2008 and 2014.

These periods were selected intentionally - the research was meant to show the difference at the beginning and the end of the programming period 2007-2013 of Cohesion policy. Slovakia is characterized by structural changes, large social disparities. It is lagging behind the EU average GDP per capita. It is particularly necessary to use allocations resources of the Structural Funds in order to maximize their impact on achieving the target problems and to approach the EU average. And the Slovak labour market is one of them. European Social Fund in Slovakia within individual regions promotes social inclusion of disadvantaged groups aiming at reducing unequal opportunities. Achieving the highest possible efficiency in the use ofEuropean Social Fund for the development of education and employment in the Slovak regions is a priority.

The questionnaire survey focused on managers of organisations was conducted within the Project 08/04-I / 3-1.2 - "The causes of discrimination in the labour market and the possibility of removing the European Social 
Fund within the EQUAL Community Initiative in 2008." This survey is followed by the empirical data collection from 2014 based on the questionnaire survey carried out by managers of organisations as the part of dissertation thesis Equal opportunities in the labour market of the Slovak Republic. In 2008 the research team, after examining the available sources and the relevant research already conducted in the area of discrimination on the labour market, prepared a detailed research plan and a questionnaire which was in a next stage individually and collectively consulted with the project management.

The main hypotheses the questionnaire was trying to verify were set as follows:

1. Employers currently perceive less discrimination against all disadvantaged groups in the labour market.

2. Employers' prejudices against Roma have not changed compared to 2008 and companies continue to show reluctance to employ Roma.

3. Older women continue to represent a group in the labour market most at risk of discrimination.
The target group of the research was composed of both public and private companies that carry out their activities on the territory of the Slovak Republic during the period of conducting the research $(2008,2014)$. A brief description of respective companies involved is summarized in Table 2. In 2008 there were 173 organizations and in 2014 there were 263 organizations that participated in the survey.

The questionnaire was anonymous. First, it contained general information about the company (type, orientation activities, number of employees, region). This was followed by a general section that was dedicated mainly to their awareness of the Slovak and European anti-discrimination legislation and to their attitudes towards it. The questionnaire also included a separate section which focused on the following selected disadvantages:

1. Age;

2. Disability;

3. Sex;

4. Belonging to the Roma minority.

The data collection in 2008 was conducted during a period of several months. Qualitative and quantitative research was carried out

\section{Tab. 2: Characteristics of companies involved in the survey $(2008,2014)$}

\begin{tabular}{l|c|c}
\multicolumn{1}{c|}{ Type of organisation } & $\mathbf{2 0 0 8}$ & $\mathbf{2 0 1 4}$ \\
\hline Public & $47 \%$ & $63.5 \%$ \\
\hline Private & $53 \%$ & $36.5 \%$ \\
\hline \multicolumn{1}{c|}{ Size of the company } & & \\
\hline Small & $49 \%$ & $82.13 \%$ \\
\hline Middle & $30 \%$ & $16.35 \%$ \\
\hline Large & $21 \%$ & $1.52 \%$ \\
\hline & & \\
\hline Bratislava & $37.5 \%$ & $17.11 \%$ \\
\hline Trnava & $5.8 \%$ & $11.79 \%$ \\
\hline Nitra & $10.7 \%$ & $7.98 \%$ \\
\hline Trenčín & $5.8 \%$ & $19.77 \%$ \\
\hline Banská Bystrica & $10.7 \%$ & $15.21 \%$ \\
\hline Žilina & $7.3 \%$ & $12.17 \%$ \\
\hline Prešov & $12.2 \%$ & $7.22 \%$ \\
\hline Košice & $10 \%$ & $8.75 \%$ \\
\hline
\end{tabular}


from March to June of 2008. Before starting the regular research the questionnaire was tested on a sample of about 50 students. The data collection was conducted in two ways: directly, through direct personal interviews as well as indirectly, by means of electronic questionnaires, phone calls and e-mails.

In 2014, the data collection took place from March to April 2014 through an online questionnaire, which was distributed via electronic mail to the relevant organizations.

The questionnaire was composed of the following types of questions: open, closed and specific with the majority of the closed questions. Processing and interpretation of the results in query was executed through an addendum to the manual, which facilitated the work of the research team.

The main purpose of this paper was to show the current state of play as well as selected developments in employment discrimination. Therefore, the results of our own research from 2008 and 2014 were consequently compared. A comparison of the current and the previous status was made possible through the methods for collecting, evaluating and processing information on the state of job discrimination in the Slovak Republic. Subsequently, we conducted a detailed, comprehensive data analysis and information obtained and the choice of optimal resources. The following sources were used for the comparison of relevant research:

- Selected data from the European Commission (Eurostat);

- Selected data from the Slovak National Centre for Human Rights;

- Information from the Central Office of Labour, Social Affairs and Family of the Slovak Republic;

- Information from the Ministry of Labour, Social Affairs and Family of the Slovak Republic.

\section{The Results and Discussion}

The issue of discrimination of some groups or persons on the labour market in the Slovak Republic is a long-term problem. Despite some improvements in the legislative area in defining equal opportunities and legal prohibition on discriminatory behaviour the results of the survey clearly confirm that the implemented activities and measures do not have sufficient effects.
The survey results obtained in 2008 and 2014 point to the fact that the majority of managers of organisations in the Slovak Republic generally recognize the European and Slovak anti-discrimination legislation that defines the area of equal treatment on the labour market. When being asked a direct question "Do you know the Slovak and the European legislations regulating the principles of equal treatment that reflects the prohibition of discrimination on the labour market?" $64 \%$ of managers in 2008 and $77 \%$ of managers in 2014 responded positively. The Slovak National Centre for Human Rights [15] also confirms that managers recognize the legislative definition of this area. A study Starší vek a l'udské práva [7] from 2011 indicates that $93.24 \%$ of managers are aware of the existing anti-discrimination legislation. That finding thus raises a question whether, in case of discriminatory practices on the labour market by managers, there is a deliberate violation of the legislation and discriminatory behaviour is so intentional and willing [11]. The answers to this question were indicated by attitudes of managers and by the comparison of results of further asked questions.

As shown in Figure 1, the managers perceived the existence of discrimination on the labour market in the two periods quite similarly. In general, as a result of improving equal opportunities on the labour market, we expected that the perception of discrimination by managers in the period of 2014 would be lower. However, it is important to take into account also external variables during the period that strongly affected the labour market, in particular the impact and consequences of the global economic and financial crisis that had an influence on the situation of equal opportunities on the labour market in the Slovak Republic.

Similar conclusions in a survey of employers in 2011 were presented also by Zozuláková [23]. As shown in her research, $79.73 \%$ of employers admit the existence of discrimination on the Slovak labour market. In most cases it occurs on the basis of age, race and ethnicity, sex, pregnancy and motherhood.

Our research has found out that managers of organisations (employers) perceive the age as the main cause of discrimination on the labour market. This is followed by disability and race or ethnic 


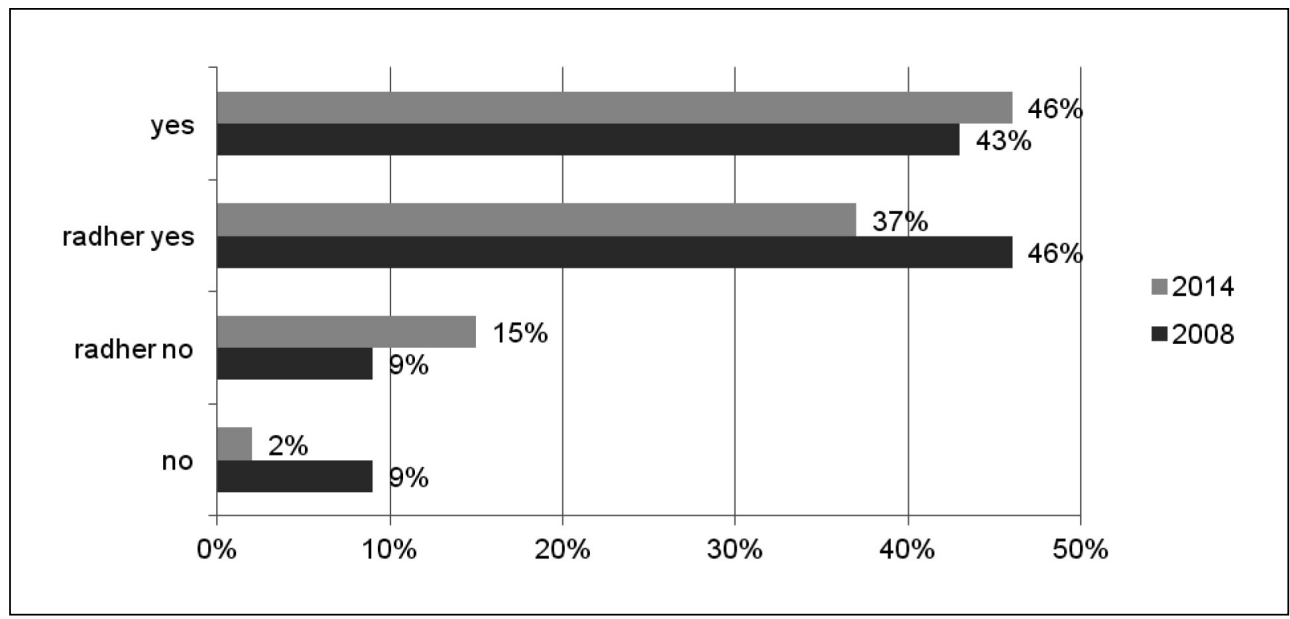

Source: own research

\begin{tabular}{|c|c|c|c|c|}
\hline $\begin{array}{l}\text { Comparison of at } \\
\text { discrimination on }\end{array}$ & $\begin{array}{l}\text { des of man } \\
\text { ese ground }\end{array}$ & $\begin{array}{l}\text { s to the exis } \\
\text { he Slovak }\end{array}$ & $\begin{array}{l}\text { ce of emplo } \\
\text { ublic in } 2008\end{array}$ & $\begin{array}{l}\text { lent } \\
\text { ld } 2014(\%)\end{array}$ \\
\hline \multirow[b]{2}{*}{ Discrimination on ground of: } & \multicolumn{2}{|c|}{2008} & \multicolumn{2}{|c|}{2014} \\
\hline & $\begin{array}{c}\text { Yes / } \\
\text { Rather yes }\end{array}$ & $\begin{array}{c}\text { Rather no / } \\
\text { No }\end{array}$ & $\begin{array}{c}\text { Yes / } \\
\text { Rather yes }\end{array}$ & Rather no / No \\
\hline Age & 92 & 8 & 92 & 8 \\
\hline Disability & 75 & 25 & 85 & 15 \\
\hline Race / Ethnic origin & 65 & 35 & 76 & 24 \\
\hline Sexual orientation & 21 & 79 & 27 & 76 \\
\hline Sex & 45 & 55 & 45 & 55 \\
\hline
\end{tabular}

Source: own research

origin. As shown in Table3, both reporting periods show very similar results in attitudes of managers of organisations regarding the main causes of discrimination. These results point to the fact that the assumption of improving the situation of disadvantaged groups in the labour market was not confirmed. In 2014, managers perceived all grounds of discrimination as equal or more significant.

The results reveal relatively strong discriminatory practices on the labour market of the Slovak Republic. That is to say, the executive managers, representing employers clearly confirmed that the discrimination is undoubtedly present in our contemporary society and has impact on their behaviour on the labour market.

The views of managers on the causes of discrimination directly correspond to the public opinion. The survey of Eurobarometer [4] conducted in 2008 assumes that $45 \%$ of respondents consider the age to be the most significant cause of discrimination on the EU labour market. It is followed by ethnic or racial origin $(42 \%)$ and disability $(41 \%)$. Taking into account the evolving situation of the disadvantaged groups on the labour market in the context of public opinion, the results of Eurobarometer $(2006,2008,2012)$ also confirm that despite the fact that it is declared to be 
one of the EU priority areas, there were no significant improvements in the area of equal opportunities on the EU labour market.

Citizens perceived the discrimination on the grounds of age more significantly in 2012 than in 2006 or 2008 . Therefore, the assumption of a positive development in this area was not confirmed. The result was rather the contrary. The public perceives the negative trend and in their opinion there is a rise in discriminatory practices based on age. In terms of sex and sexual orientation as grounds of discrimination in the surveyed period, the EU citizens did not perceive any significant improvements. Activities and efforts to ensure gender balance in comparison to the other characteristics are much stronger, older and more complex on both levels - the European and the national ones. Nevertheless, neither the managers nor the public saw any significant improvements in relation to this characteristic.

Why are the positive trends neither observed nor statistically recorded in relation to disadvantaged groups on the labour market? As a matter of fact, the managers are the ones who have the power that can be used for the benefit of the labour market participants. How is it therefore possible that there is no significant improvement in fostering equal opportunities in practice despite the fact that legislation explicitly prohibits discriminatory behaviour on the labour market and the managers recognize the legal definition of discrimination and are aware of their obligations? Provided that managers are equally sensitive to the grounds of discrimination are they not equally tolerant to stereotyped perception of prejudices based on common characteristics?

All organizations are composed of people. Discriminatory behaviour is human behaviour against certain individuals or groups. People in organizations and managers are part of the society where some stereotypes and prejudices against certain groups and individuals might occur. Thus, if the public tolerates these prejudices, will not the managers as an important part of the society treat similarly also the participants on the labour market and thus promote the "culture of discriminatory practices"?

In view of the objective of verifying whether managers of organisations purposely discriminate against selected groups on the labour market in the Slovak Republic the research suggests that this is a conscious act. This statement might be emphasized by answers to the following questions:

1. If you had a chance to choose from several candidates for the job, while all the candidates have meet the required qualifications and differ only by their age and sex, which of the following candidates would you prefer? [Options 1-4: 1. A young woman - a young man; 2. A woman in middle age - middle-aged man; 3. An elderly woman - an older man; 4. A distinction based on age is not important].

2. Would your company allow a member of your staff who just became disabled to remain at his job, provided that the disability would not prevent this disabled person to carry out his/her duties?

3. Do the Roma people have the same chances to succeed in the admission procedure for the vacant post in your organization like other people from the majority population?

Managers in the questionnaires admitted that provided that they would be in a position to decide on employing a candidate solely on the basis of age and sex, they would clearly select a middle-aged man. When comparing the following pairs solely on the grounds of sex: "A young woman - a young man; A middle-aged woman - a middle-aged man; An older woman an older man"; it is generally a man that is the preferred option. As confirmed by managers in both reporting periods $(2008,2014)$ the least preferred option to managers is an older woman. The above results show that when merging several characteristics intone single person-a participant on the labour market we may speak of multiple discrimination, based on both the grounds of the age and sex characteristics. If we take into account also examining the other characteristics, the research results might be found even more interesting. For example, taking into account the ethnic or racial origin, based on the obtained results of the research we can say that in particular Roma women are facing multiple disadvantages on the labour market.

The answer of the managers to question 2 whethertheir organisation would allow a member of their staff who just became disabled to remain at his job, provided that the disability would not prevent this disabled person to carry out his/her duties, there were some positive developments. While in $200859 \%$ of managers responded positively, in 2014 the number of positive answers increased 
to $76 \%$. It should be, however, pointed out to the relatively high percentage of managers who responded negatively. These managers thus admitted that they purposely discriminate a potentially disabled employee.

In terms of employment of disabled persons it should be emphasized their minimum involvement into the labour market in the Slovak Republic. According to Pufflerová, in 2008 [12] the employment of disabled persons was on the level of $9 \%$, while as the consequence mainly of the economic crisis the employment rate of disabled dropped. The results of questionnaire surveys as well as the relevant statistics confirm that the disabled in the Slovak labour market are in a difficult position and that there still exists a certain gap between the labour market and its disabled participants.

In a long term, one of the most disadvantaged groups on the Slovak labour market can be considered the Roma group. The existing prejudices, vulnerability to poverty, social exclusion, lack of education, frequent segregation and marginalization of this group certainly have a negative effect on the situation of the Roma in the labour market. The managers of organisations participating in the survey admitted that belonging to the Roma minority means a serious obstacle towards an employment access on the Slovak labour market. The managers in both reference periods admitted that Roma job seekers at the selection procedure for the vacant post do not have the same chances as other nonRoma job applicants. In 2008 this statement was confirmed by $30 \%$ of managers, while in 2014 , admitted this fact a little less, i.e. $26 \%$ of managers. This development can therefore indicate some positive trends in the perception of the Roma on the labour market. On the other hand it must be highlighted that there is still relatively high percentage of managers who openly admitted discriminatory practices against some groups in the labour market, taking account the belonging of these groups to a particular race or ethnicity. The Table 4 shows the most frequent

\begin{tabular}{c|l} 
Tab. $4:$ & $\begin{array}{l}\text { Most frequent causes for refusing to employ Roma applicants } \\
\text { as stated by the managers in the Slovak Republic }\end{array}$ \\
\hline Order & \\
\hline $1^{\text {st }}$ & "Insufficient level of education and qualification"; \\
\hline $2^{\text {nd }}$ & "Reputation of unreliable workers"; \\
\hline $3^{\text {rd }}$ & "Reputation of workers without work ethics and/or discipline"; \\
\hline $4^{\text {th }}$ & "Reputation of workers without motivation"; \\
\hline $5^{\text {th }}$ & "Existence of racial prejudice against Roma"; \\
\hline $6^{\text {th }}$ & "Reluctance of companies to employ Roma". \\
\hline
\end{tabular}

causes why the managers generally tend not to select the Roma job applicants.

The order of the above mentioned causes why the managers generally tend not to select the Roma job applicants is identical in both researched periods $(2008,2014)$. However it should be noted that the research results reveal slight improvements of the image of the Roma by managers and this shows certain positive trends in this area. These research results therefore respond to the research objective as mentioned in part 1 that aimed "to show the evolution of the labour market in terms of disadvantaged groups in order to identify whether any change of the situation of selected groups of participants on the labour market occurred".

However, it is important to emphasize the regional aspects that play an important role in the interpretation of the results. While in 2008 more than $22 \%$ of the organizations involved were from Eastern Slovakia, in 2014 it was less than $16 \%$. The perception of the Roma ethnic group in the respective regions of Slovakia significantly varies. Our research conducted in 2014 showed that $\mathbf{5 0 \%}$ of managers in the Eastern Slovakia generally consider the Roma citizens to be discriminated. It is worth adding that the Eastern Slovakia is also 
region with the largest Roma population as well as the segregation of this group in the Slovak Republic. The managers of organisations in Eastern Slovakia do not consider the following factors to be the most important grounds of discrimination of the Roma: level of education, qualification, and of long-term unemployment. The managers rather realize the impact of these factors on the real opportunities of the Roma minority in the region.

In the Bratislava region, $76 \%$ of managers claimed that Roma are discriminated on the labour market. In comparison to the region of Eastern Slovakia this represents a significant difference. That is why, the issue of Roma discrimination is perceived differently by the managers of organisations who are less likely to come into contact with this group as by those who have real practical experience with this group. Results from 2008 did not confirm this thesis, so the above mentioned statement should not be generalized. However, in the context of the findings of the Regional Centre for United Nations Development Program [13] which confirms the direct relation between level of education of the Roma and their employment rate it is possible to consider the existence of some relation. That is to say, the managers of organisations in the Slovak Republic often consider the low level of education and qualifications as the main cause of the disadvantaged position of the Roma on the labour market. Higher education, however, is achieved by the Roma, provided that they are outside of segregated groups, freely dispersed among the majority population. The problems of the Roma group are quite differently perceived by managers of organisations in the region of the Western Slovakia, where Roma do not live in their own villages separated from others and at the same time differently by managers of organisations in the Eastern Slovakia, with much larger share of the Roma minority that is perceived to be less discriminated.

Based on the results of a questionnaire survey of managers and their mutual comparison it therefore should not be unambiguously stated that in comparison to the previous researched period there is a clear improvement in equal opportunities for selected groups on the labour market. Although the answers to some questions seem to be in favour of the disadvantaged groups, the others seem to be contradictory to positive developments. It is therefore necessary to look for reasons that are an obstacle towards the improvement of the situation of equal opportunities on the labour market.

In terms of legislative definition of the area of disadvantaged groups on the labour market the Slovak National Centre for Human Rights [13] and the Ministry of Labour, Social Affairs and Family [10] stated that Slovakia has comparable anti-discrimination legislation with most of the EU countries and it covers even several aspects of discrimination compared with the European directives. However, as

\section{Fig. 2: Attitudes of managers of organisations in the Slovak republic towards the effectiveness of application of anti-discrimination legislation $(2008,2014)$}

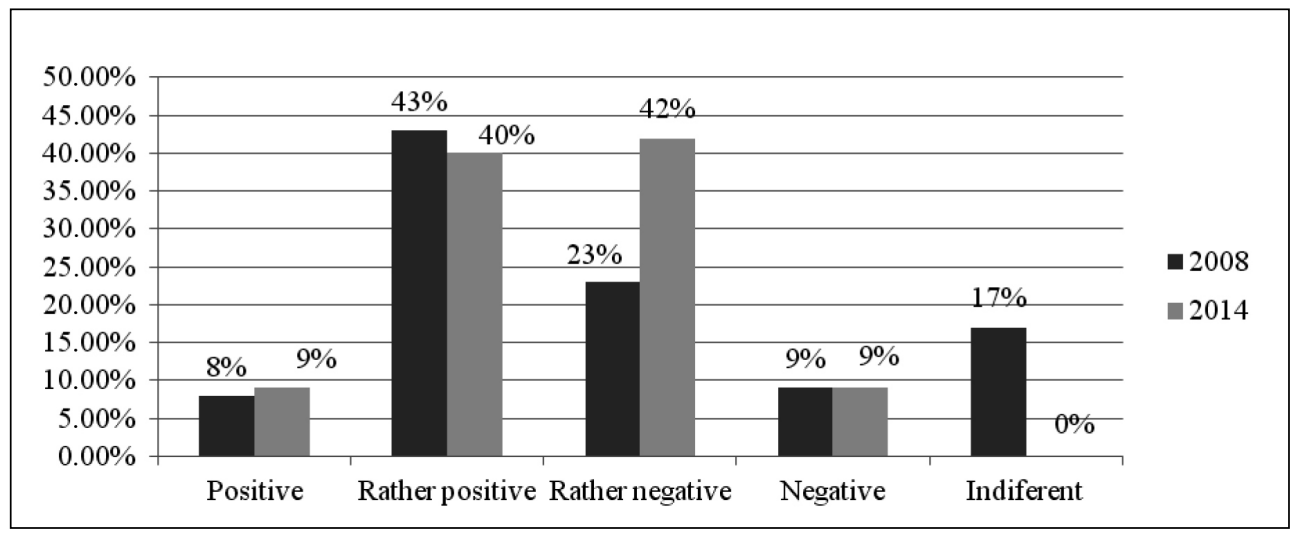

Source: own research 
confirmed by the research results shown in Figure 2, the organizations are considerably sceptical about the effectiveness of Slovak and European anti-discrimination laws.

Why is the anti-discrimination legislation in Slovakia not regarded by the managers as sufficiently effective? Is this currently a problem of legislation or is it due to a complicated procedure of introduction of legislative acts into practice? It should be acknowledged that one of the main problems in the Slovak Republic in relation to equal opportunities on the labour market remains weaker protection of temporary jobs in comparison to a strong protection of permanent jobs that is certainly lowering chances of disadvantaged groups to have a more stable employment. That is to say, the disadvantaged groups - young people, elderlies, the Roma, the disabled persons work on temporary basis more frequently than other labour market employees who have much better chances to find a permanent job. The Slovak Republic lacks also the legislation ensuring sufficient flexibility among labour relations, in particular regarding the organization of work and the working time. This has the most negative impact particularly on the disadvantaged labour market participants.

Thus, if we consider the problems of the Slovak anti-discrimination legislation, we should reflect in a wider context and consider different aspects. However, despite some shortcomings, this area should not be judged as insufficiently legally defined or as a noncomplex, rather the contrary. So what is the main cause that managers perceive the legislative definition of this area as insufficient and ineffective? The legislative acts in the field of equal opportunities in the labour of the Slovak Republic might be perceived to be only formal documents, which is a consequence of the lack of support in this area on the national level. Within the Slovak labour market conditions, the Government approach to the issue of disadvantaged groups is not explicit enough that is causing further problems and supports the persistence of discriminatory practices on the Slovak labour market. Within this area, we can, therefore speak of a certain "vicious circle". That is to say a lack of application of legislative measures through institutional mechanisms implies indifference or ignorance from the side of the organizations on equal and non-discriminatory approach. It has also an effect on the persistence of handicaps and stereotyping and on the acceptance of the established prejudices. This is directly affecting the situation of some vulnerable groups or persons on the labour market and contributes to their exclusion from the formal labour markets.

\section{Conclusions}

The aim of this paper was to reveal the current situation of selected disadvantaged groups on the labour market in the Slovak Republic from the point of view of managers of selected organisations, using the method of questionnaire survey. In the context of developments in selected research periods $(2008,2014)$ we tried to examine the attitudes of managers of organisations in the Slovak Republic towards selected disadvantaged groups and verify the existence of discriminatory behaviour by managers against these groups. Some results point to increased tendencies of more negative perception of disadvantaged groups by the managers, we could consider the general deterioration of these groups on the labour market. In particular, the perception of causes of discrimination is stronger or equal in the period of 2014 in comparison to the same period of 2008 - for the following characteristics: age, disability, race / ethnicity, sex, sexual orientation. The most common discriminatory experience of Slovak citizens is the age discrimination.

On the other hand the answers of managers to questions regarding the knowledge of anti-discrimination legislation suggest some improvements in comparison to the previous reference period. Thus, if managers are familiar with the legislation in this field, the principle of equal treatment and non-discrimination definition, should it not lead to some tangible improvements in this area?

The achieved results could be well used for further researched on and/or implemented particularly in areas of management and education [14]. We fully share the view of Uramová and Hronec [16] who emphasize the necessity to remove "barriers to better matching ofeconomiceducation and labourmarketneeds". However we need to realize that the managers are those who can significantly influence the course of events in the labour market from the perspective of disadvantaged groups. They have the power that might and should be used towards continuous effort for inclusion of these 
groups. Managers themselves are responsible for choosing whom they will engage; decide on how they will reward their workers, on the working conditions of the workers, on the promotion within the organization process, or on determining the remuneration system. Thus, if managers know they cannot, or should not, judge participants on the labour market solely on the basis of certain selected characteristics, some improvements can be expected. It should however be taken into account that managers are an important part of the society. And if there are existing prejudices, will the managers subconsciously not be less sensitive towards these disadvantaged groups on the labour market?

The familiarization with the issue of discrimination brings also its more sensitive perception in real life. It is therefore very important to promote any raise of discrimination awareness. Based on the conclusions of the research analysis, it is necessary to pay particular attention to raising awareness, and the associated sensitivity to issues relating to discriminatory practices on the labour market and the possibilities of protection against them. This activity should be carried out by both sides - the employees and the managers. From this perspective, it could be the most appropriate - in cooperation with the Slovak media - to initiate a continuous public discussion about the issues of discrimination.

The results of our research confirmed the presence of discriminatory behaviour on the labour market in the Slovak Republic. Managers openly admitted their discriminating behaviour and favouring certain groups or participants on the labour market. The results of this research have revealed the complicated situation of these groups on the Slovak labour market and that improvements in this area are very modest, or, almost none. The current economic situation, however, requires continuing in efforts to create an environment of respectful of individual freedom, responsibility, morality, private property and equality of opportunities. It is necessary to abandon the inefficient measures, the complex institutional mechanisms and acceptance of discriminatory behaviour, not only on the labour market but in all areas of the society. This is not the right way neither towards a truly "free and competitive market", nor to greater equality of opportunities. It might be expected that in economic management processes as well as in case of hiring new employees completely different criteria should be fulfilled.
Within the European Union, the Slovak Republic belongs to the group of states where the equal opportunities on the labour market do not reach the EU objectives. Slovakia's below-average level in this area is confirmed by the relevant statistics. Finding the causes of the situation is a demanding process. However, provided that some people are denied access to a certain employment, for which they are qualified, solely on grounds of their national origin, race or other irrelevant characteristics, it might be a sign that the society sacrificed equality in opportunities and therefore the freedom of all to the benefit of one or a few "selected" groups.

The current programming period 2014 2020 has just started, so Slovakia has the opportunity to show its great potential to draw EU funds successfully, and particularly in areas that are strategically important for Slovakia primarily reduce long-term unemployment and regional disparities.

The authors are well aware of the sensitivity of the issue of discrimination that tends to be misused by individual pressure groups for their particulate intentions that might be in contradiction with the idea of the "common good" of the society. One of key responsibilities for all members of the society is to make a continuous effort in creating adequate conditions for overall development and for limiting tensions in the society. This principle is in direct contradiction with providing opportunities for creation antagonist groups based on stereotyped prejudges against natural diversity that existed since ever. Antagonism leads to segregation of vulnerable groups that can be hardy considered to be in the interest of a well functioning contemporary society.

On the other side it should be taken into account that the requirements of managers who are responsible for economic results and thus naturally seek to employ the candidate who matches the job requirements in the best way are fully legitimate. This priority of natural economic behaviour in a turbulent and highly competitive economic environment should not be underestimated. However it should be emphasized the need for balanced approach for both the managers and the disadvantaged groups, based on consistent respect of human dignity that allows both, the organisations to remain highly competitive as well as the disadvantaged groups to become gradually 
more and more involved in the labour market. It is a moral imperative of a society based on true freedom and solidarity, without which the common Europe and the modern civilisation have no sustainable future.

\section{References}

[1] ALTONJI, J., BLANK, R. Race and Gender in the Labour Market. Handbook of Labor Economics. 1999, Vol. 3, Part: C, pp. 31433259. ISBN 978-0-444-50189-9. DOI: 10.1016/ S1573-4463(99)30039-0.

[2] ARROW, K.J. Collected Papers of Kenneth J. Arrow. Volume 1: Social Choice and Justice. Belknap Press, 1983. 240 pp. ISBN 978-06741376-08.

[3] BALDWIN, M. An asymmetric information theory of labour market discrimination. Southern Economic Journal. 1991, Vol. 57, Iss. 4, pp. 1148-1154. ISSN 0038-4038.

[4] EGER, L., INDRUCHOVA, Z. Diversity Management - Perceptions and attitudes by Czech Managers. E+M Ekonomie a Management. 2014, Vol. 17, Iss. 1, pp. 73-81. ISSN 1212-3609. DOI: 10.15240/tul/001/2014-1-006.

[5] EUROPEAN COMMISION. Eurobarometer 2012 on perceptions of discrimination in the EU [online]. Brussel: EC, 2012 [cit. 2015-0516]. Available from: http://ec.europa.eu/justice/ newsroom/discrimination/news/121122 en.htm.

[6] EUROPEAN FOUNDATION FOR THE IMPROVEMENT OF LIVING AND WORKING CONDITIONS. Equal Opportunities [online]. Dublin: Eurofound, 2011 [cit. 2015-05-16]. Available from: http://www.eurofound.europa. eu/areas/industrialrelations/dictionary/ definitions/equalopportunities.htm.

[7] FILADELFIOVÁ, J., et al. Starší vek a l'udské práva: silnejšia participácia, menej diskriminácie [online]. Inštitút pre verejné otázky, 2011 [cit. 2015-05-31]. 42 p. (PDF). Available from: http://www.ivo.sk/buxus/docs// vyskum/subor/Prezentacia_IVO_Starsi_ vek_a_ludske_prava_marec_2012.pdf.

[8] JACOBY, H.G. How social hierarchy impedes economic mobility. Journal of Economic Behavior and Organization. 2001, Vol. 117, pp. 135-154. DOI: 10.1016/j.jebo.2015.05.003.

[9] KORIMOVA, G. Ekonomika a manažment sociálneho podniku. E+M Ekonomie a Management. 2006, Vol. 9, Iss. 4, pp. 98-103. ISSN 1212-3609.

[10] MINISTERSTVO KULTÚRY SLOVENSKEJ REPUBLIKY. Kultúra znevýhodnených skupín obyvatel'stva [online]. Bratislava: MKSR, 2014 [cit. 2015-05-16]. Available from: http://www. culture.gov.sk/posobnost-ministerstva/kulturaznevyhodnenych-skupin-obyvatelstva--115.html.

[11] MOHELSKÁ, H. Jak vybrat vhodné zaměstnance. E+M Ekonomie a Management. 2005, Vol. 8, Iss. 4, pp. 75-78. ISSN 1212-3609. [12] PUFFLEROVÁ, Š. Slovensko, správa č. 1 [online]. Bratislava: ODZ, 2009 [cit. 2015-0518]. Available from: odz.sk/wp-content/uploads/ Slovakia_Report_01_SK.doc.

[13] REGIONÁLNE CENTRUM ROZVOJOVÉHO PROGRAMU OSN PRE EURÓPU A SPOLOČENTVO NEZÁVISLÝCH ŠTÁTOV V BRATISLAVE. Správa o životných podmienkach rómskych domácností na Slovensku [online]. 2012 [cit. 201505-18]. Available from http://hatemetoo.sk/wpcontent/uploads/2013/03/UNDP+sprava.pdf.

[14] SEMRÁDOVÁ, I., KACETL, J. Ethics in the future manager's professional training. $E+M$ Ekonomie a Management. 2011, Vol. 14, Iss. 2, pp. 79-89. ISSN 1212-3609.

[15] SLOVENSKÉ NÁRODNÉ STREDISKO PRE L'UDSKÉ PRÁV. Výhody diversity a implementácie nediskriminačných mechanizmov v praxi [online]. Bratislava: SNSL'P, 2011 [cit. 2015-05-18]. Available from: http://www. diskriminacia.sk/archiv/?q=node/1920.

[16] URAMOVÁ, M., HRONEC, M. Identification of Barriers to Better Matching of Economic Education and Labour Market Needs. In: Proceedings of the 10th International Conference Liberec Economic Forum 2011. Liberec: Technical University of Liberec, 2011. pp. 527-535. ISBN 978-80-7372-755-0.

[17] VAGAČ, L'. Diskriminácia, teória, legislatíva a prax [online]. 2011 [cit. 2015-0516]. 49 p. (PDF). Available from: http://www. ineko.sk/projekty/centrum-socialneho-dialogu.

[18] VÁGNEROVÁ, M. Psychopatologie pro pomáhajíci profese. Variabilita a patologie lidské psychiky. Praha: Portál, 2002. 444 p. ISBN 80-7178-678-0.

[19] YINGER, J. Evidence on Discrimination in Consumer Markets. Journal of Economic Perspectives. 1998, Vol. 12, Iss. 2, pp. 23-40. ISSN 0895-3309. DOI: 10.1257/jep.12.2.23.

[20] WORLD BANK. Engendering Development. A World Bank Policy Report. New York: Oxford University Press, 2001.

[21] Zbierka zákonov č. 460/1992. Ústava Slovenskej republiky.

[22] Zbierka zákonov č. 280/2013. Zákon o službách zamestnanostia o zmene a doplnení niektorých zákonov. 
[23] ZOZUL'ÁKOVÁ, M. Diskriminácia osôb na trhu práce. Mosty inklúzie [online]. Bratislava: Národná rada občanov so zdravotným postihnutím v SR, 2011 [cit. 2015-05-18]. Available from: http://www.nrozp-mosty.sk/archiv/item/911.

doc. PhDr. René Pawera, PhD. Comenius University Faculty of Management Department of Economics and Finance Rene.Pawera@fm.uniba.sk
PhDr. Vladimíra Pazderová, PhD.

Comenius University

Faculty of Management

Department of Economics and Finance

Vladimira.Stefancova@fm.uniba.sk

doc. PhDr. Marian Šuplata, PhD.

Matej Bel University

Faculty of Economics

Department of Economics

Marian.Suplata@umb.sk 


\section{Abstract}

\section{ATTITUDES OF MANAGERS TOWARDS DISADVANTAGED GROUPS ONTHE LABOUR MARKET IN THE SLOVAK REPUBLIC}

\section{René Pawera, Vladimíra Pazderová, Marian Šuplata}

Discrimination is a serious long-term problem, being faced by all parts of our society, including the labour market. This is particularly a case for some vulnerable groups who in search for an employment are facing serious problems.

The aim of this paper is to focus on the current situation of disadvantaged groups on the labour market of the Slovak Republic from the point of view of managers of selected organisations. By the method of questionnaire survey of the managers we were examining their attitudes towards selected disadvantaged groups on the labour market. Furthermore we examined the motives of the managers in relation to the employment of selected candidates pointing to the discriminatory or nondiscriminatory behaviour of managers on the Slovak labour market. In our research we also focus on the evolution of the labour market in terms of disadvantaged groups in order to identify whether any change of the situation of selected groups of participants on the labour market occurred.

The purpose of our analysis also is to verify whether managers discriminate selected groups of participants on the labour market intentionally and whether there exists any shift in the perception of these groups by the managers.

In order to fulfil this objective we conducted a questionnaire survey focused on selected managers of organisations, in two reference periods: 2008 and 2014.

The target group of the survey was composed of both public and private companies that carry out their activities on the territory of the Slovak Republic during the period of conducting the research.

Key Words: Discrimination, employers, labour market, managers, organisation, Slovak Republic.

JEL Classification: J71, M14, M54.

DOI: 10.15240/tul/001/2015-4-003 